\title{
OTHER BOOKS
}

Dossick, Jesse J. Doctoral Research on Russia and The Soviet Union, 19601975. A Classified List of 3,150 American, Canadian, and Bitish Dissertations With Some Critical and Statistical Analysis. Garland Publishing. Inc., New York, London 1976. xxiv, 346 pp.

Gimpel'son, E. G. Sovetskij rabočij klass 1918-1920 gg. Social'no-političeskie izmenenija. Izdatel'stvo "Nauka", Moskva 1974. 352 pp.

Rabočee dviženie v Rossii v 1901-1904 gg. Sbornik dokumentov. Izdatel'stvo "Nauka", Leningradskoe otdelenie, Leningrad 1975. 591 pp.

\section{NOTES ON CONTRIBUTORS}

Geoffrey Alderman is Lecturer in the Department of History, Royal Holloway College, University of London, Egham, Surrey.

Robert G. Neville is a researcher in the Department of Education, University of Leeds, Leeds, and a course tutor with the Open University.

$R$. Bean is Senior Lecturer in Economics in the University of Liverpool, Liverpool.

John Rule is Lecturer in History in the University of Southampton, Southampton. 